\title{
Awareness and Constraints of Aquaculture Biosecurity Among Fish Farmers in Ekiti State, Nigeria
}

\author{
Siyanbola A. Omitoyin ${ }^{1, *}\left(\mathbb{D}\right.$, Kemisola D. Osakuade ${ }^{1}$ \\ ${ }^{1}$ University of Ibadan, Department of Aquaculture and Fisheries Management, Nigeria.
}

\begin{abstract}
How to cite
Omitoyin, S.A., Osakuade, K.D. (2021). Awareness and Constraints of Aquaculture Biosecurity Among Fish Farmers in Ekiti State, Nigeria. Aquaculture Studies, 21, 83-92. http://doi.org/10.4194/2618-6381-v21_2_05
\end{abstract}

\section{Article History}

Received 15 September 2020

Accepted 01 February 2021

First Online 08 February 2021

\section{Corresponding Author}

Tel.: +2348033246790

E-mail: sbomitoyin@yahoo.com

\section{Keywords \\ Curtailment \\ Disseminate \\ Fish Disease \\ Precaution}

\begin{abstract}
The study investigated the level of awareness and constraints the farmers were facing in adopting effective biosecurity measures in Ekiti State. Primary data were collected using multi-stage sampling technique to randomly select 150 fish growers, out of which 144 questionnaires were recovered. Analysis was carried out using descriptive statistics, four-point Likert scale and multiple regression. The result showed that $76.4 \%$ of the fish farmers with mean age of $40.48 \pm 10.28$ years were married, $61.1 \%$ owned the land on which they farm their fish, $73.6 \%$ operated as small scale fish farmers with farm size of $<1$ hectare. About $91.0 \%$ knew about fish diseases, the main source of pollution on the farm was flooding while some (61.1\%) experienced outbreak of fish diseases at juvenile stage. High cost of facilities, lack of financial assistance, poor knowledge on biosecurity, expensive laboratory charges and inadequate monitoring by extension agents was perceived as the major constraints. The farmers need financial help to get adequate facilities and to enlarge their scale of operation. Adequate extension services to enlighten them on the effective biosecurity measures should be adopted.
\end{abstract}

\section{Introduction}

Fish is a reasonably priced and important resource of animal protein which contains vitamins, minerals and oils with low level of cholesterol (Odoh et al., 2019). Gradual increase in human populace, revenues, and demography has brought about a rise in fish consumption due to of its nutritional significance over the years (FAO, 2014). However, there has been gradual decline in capture fisheries due to pressure from overfishing, climate change, pollution and the likes, yet, human population is rising daily and is expected to reach about 8.6 billion, 10.1 billion and about 12.7 billion by 2030, 2050 and 2100, respectively (UN, 2019). Therefore, to make sure we are food secured, there is need to increase the production of protein-based foods for this ever increasing population through sustainable fish farming (Onyekuru et al., 2019).
Fish farming is speedily advancing among other agricultural sectors because it has the tendency to create job opportunities and ensure there is no paucity of food because it is providing an exceedingly nourishing animal protein as well as indispensable micronutrients amid susceptible and vulnerable households (Ye and Cochrane, 2011; FAO, 2012). Fish farming has rapidly attained impetus as a ground-breaking and profitable means of providing employment and enriching household revenues within sub-Saharan Africa (Shava and Gunhidzirai, 2017). Nigeria now ranks amongst Africa's largest producers of fish, only second to Egypt, whose aquaculture products have Nigeria as its main African market destination. The most cultured fishes are catfish and tilapia, but the country has the environment to support the farming of other tropical species in both fresh and marine water environments (Fact sheet, 2019). In spite of the domestic production reported to 
be approximately 800,000 metric tonnes, Nigeria still have about 1.3 million metric tonnes of fish to meet up with 2.1 million metric tonnes of yearly fish required. Nigeria however imports about 1.9 million metric tonnes of fish per annum to be able to meet the gap in the demand-supply (Agbo, 2015).

The intensive culture of food fish which is intended to optimize fish production has led to outbreaks of various diseases, resulting in annual economic losses estimated at billions of dollars worldwide (Pridgeon and Klesius, 2012). According to Mutibvu et al. (2012) disease crisis, scarcity of quality water and feed as well as ineffective extension service delivery are the grave restriction on advancement of animal production fish inclusive while Adams and Yankyera (2015), reported that diseases and pests menace, insufficient veterinary offices and animal health professionals were the major three constraints affecting animal health management in northern Ghana.

According to Huicab-Pech et al. (2016), a higher percentage of fish diseases (90\%) in a controlled aquatic environment are associated with improper husbandry practices and inadequate implementation of biosecurity measures. Diseases have become one of the major challenges to aquaculture sustainability, reducing the efficiency by which input is converted into output (Brun et al., 2009). Diseases are causing reduction in the quality of the fish, loss of market access, increment in environmental infectious load and loss of jobs. Most aquaculture disease outbreaks have occurred in developing countries where over 90 percent of aquaculture takes place, reducing revenues, eliminating jobs, threatening food security, and undermining development goals. The generally small-scale and rural nature of aquaculture in developing countries means that the vast majority of diseases go undiagnosed, untreated, and undocumented, imposing an enormous burden on communities working to escape poverty (UNCTAD, 2018). Most important diseases affecting farmed fish have been unexpectedly carried to non native areas because of improper biosecurity measures (Noga, 2010). Biosecurity began as a set of precautionary measures designed to reduce the risk of transmission of infectious diseases in crops and livestock, quarantined pests, invasive alien species, and living modified organisms (Koblentz, 2010). A sound biosecurity program for a fish or shellfish aquaculture facility is intended to incorporate disease prevention, disease monitoring, cleaning and disinfection between production cycles and general security precautions (Smith, 2012). Good biosecurity also includes reducing stressful conditions that can make fish more susceptible to disease; this involves the practices, habits, procedures and policies used to prevent the introduction and spread of disease causing organisms as well as invasive species. The fundamental on-farmstead biosafety standards as documented by Assefa and Abunna (2018) should consist of the following: "isolation of a new fish stocks previous to stocking within existing fish stocks/isolation of dead fish, sanitation, traffic management, sterilization of water, and allocation of risk-free feed". There are numerous potential sources of entry for an infectious agent into an aquaculture facility, which include additions of new stock, contaminated water or feed; humans, animals or equipment and subclinical carriers within the existing stock.

Increased fish production is needed to boost food security for the ever increasing human population, coupled with declined in catch from the wild. All hands must be on desk to ensure that the introduction or spreading of diseases and diseases causing agents are reduced to the barest minimum in the aquaculture sub sector towards adoption of biosecurity measures at all levels to improve fish production and ensure food availability. Therefore, this study was designed to examine the level of awareness and constraints of biosecurity measures sin the study the area.

The main objective of this study is to examine the level of awareness and constraints of biosecurity measures among farmers in Ekiti state, Nigeria. The specific are:

1. To examine some socio-economic characteristics of fish farmers in Ekiti State

2. To ascertain the awareness of farmers on the prevalence of fish diseases and transmission routes in the study area

3. To examined the constraints to adoption of effective biosecurity measures in the study area

\section{Materials and Methods}

\section{Description of the Study Area and Data Collection}

The research work was carried out in Ekiti-State, Nigeria (Figure 1). Ekiti state is located between Longitude $4^{0} 5^{1}$ and $5^{0} 4.5^{1}$ East of the Greenwich meridian and Latitudes $7^{0} 15^{1}$ and $8^{0} 5^{1}$ North of the Equator in Southwestern Nigeria and covers an area of $6,353 \mathrm{~km} 2$. Its climate is of the West Africa monsoon type with dry and wet season, its annual rainfall ranged from $750 \mathrm{~mm}$ in the northern zone to $1200 \mathrm{~mm}$ in the southern zone, temperature ranges between $21^{\circ} \mathrm{C}$ to $34^{\circ} \mathrm{C}$ with little variation throughout the year and annual average relative humidity is about $90 \%$ at 7:00am and $65 \%$ at 4:00pm. Two distinct types of vegetation are predominant in the study area namely; the derived savannah vegetation to the northern peripheries and the rain forest belt covering larger percentage of the total land area to the south (Olujobi et al., 2013). The land is buoyant in agricultural resources with cocoa as its leading cash crop (Bakare et al, 2014).

\section{Data Size and Sampling Technique}

One hundred and fifty (150) fish farmers from the three ADP zones in Ekiti State were chosen through multi-stage sampling technique (ADP zones to blocks to cells). Forty (40) respondents were randomly chosen 


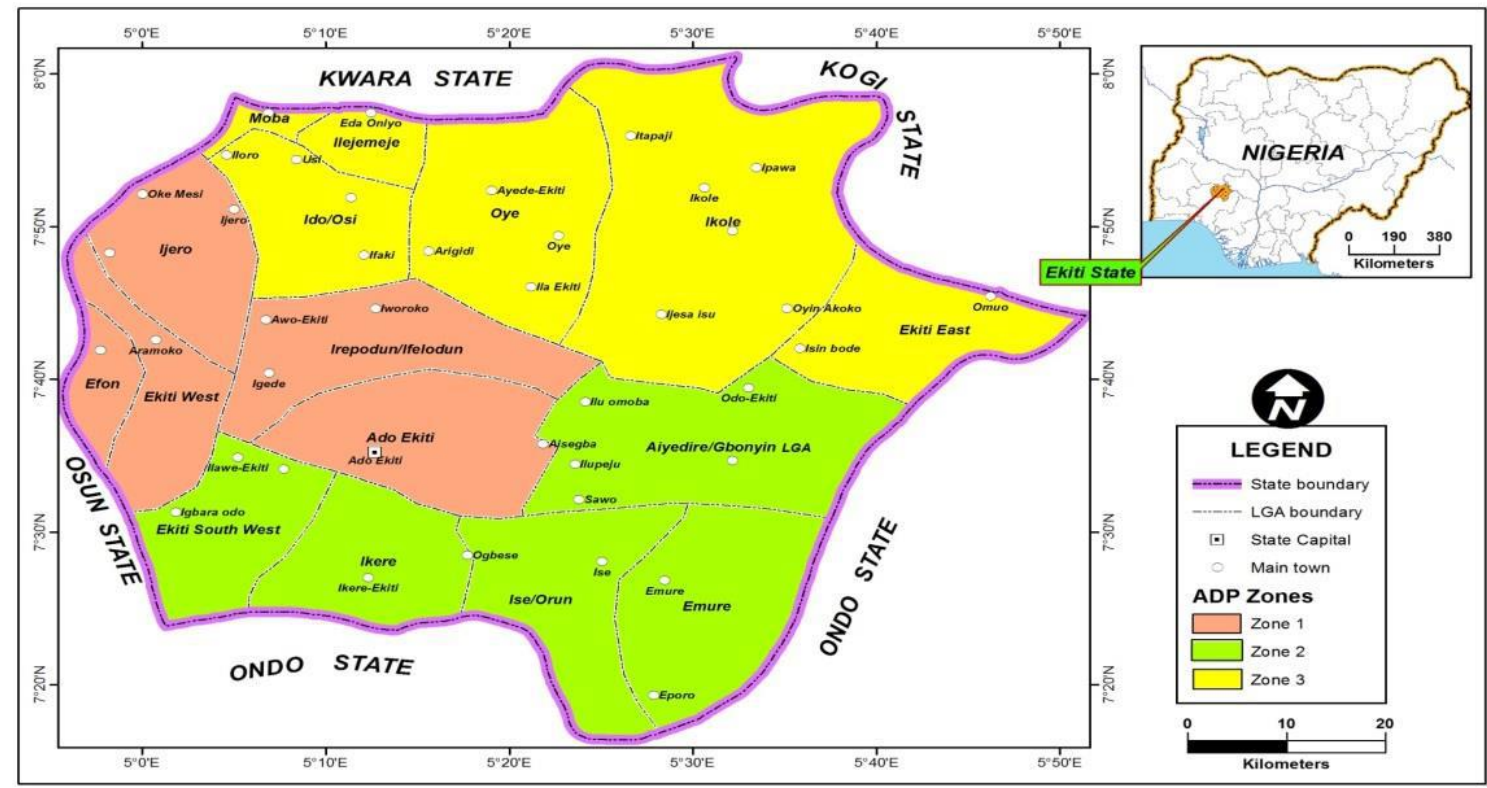

Figure 1. Map of Ekiti State Showing the three ADP zones in the state

from 5 blocks in lkere zone out of which four cells were selected from each of the 5 blocks. Forty (40) respondents were randomly chosen from 6 blocks in Isan zone out of which three cells were randomly selected, then seventy (70) respondents were selected from 5 blocks in Aramoko zone, being the zone with the largest number of fish farmers according to the information gathered from Ekiti State Ministry of Agriculture and Natural Resources (Fisheries Department). Information was collected from the respondents on their awareness and constraints they face in adopting some effective biosecurity measures on their fish farms through structured questionnaires. 144 questionnaires were recovered and analysed out of the 150 questionnaires which were administered.

\section{Data Analysis}

Data obtained from the field was subjected to descriptive (frequency counts, mean and percentages) and inferential statistical analysis, using Statistical Package for Social Sciences (SPSS-Version 21) software. In ascertaining perceived constraints faced by the fish farmers in adopting biosecurity measures on how to enhance fish production, a four-point Likert-type scale with options of strongly agree, agree, disagree and strongly disagree with nominal values of $4,3,2$ and 1 respectively was used to obtain responses from fish farmers.

\section{Results}

\section{Socio-economic Characteristics of the Respondents}

Data on the socio-economic characteristics of the fish farmers is presented in Table 1, this showed that $76.4 \%$ of the respondents were married while only
$23.6 \%$ were singles, $43.1 \%$ had a household size that ranged between 5 and 6 with a mean of $2.04 \pm 0.84$, $65.3 \%$ of the respondents encountered were within the age range of 30 and 39 years (39.6\%) with mean age of $40.48 \pm 10.43$. Also, $61.1 \%$ of the fish farmers own the land on which they carried out their fish farming activities. The analysis also showed that majority of the respondents had a monthly revenue above N70,000 from both fish farm profit and their off-farm income. This indicated that fish farming business is lucrative enough to be a source of revenue to fish farmers to sustain their family.

\section{Fish Farming Management Systems in the Study Area}

Table 2 showed $96.1 \%$ of the respondents were involved in monoculture, while just a few (6.9\%) practiced polyculture. It was observed that $73.6 \%$ of the fish farmers operated on small scale with a land size less than 1 hectare. About 33.3\% of the fish farmers produced between 1 and 2 tons of catfish per production cycle. This low production might not be unconnected with the small scale production level.

\section{Level of Awareness of Fish Farmers in Ekiti State on Fish Disease}

The fish farmers' awareness of fish diseases (Table 3) showed that $91.0 \%$ of the respondents knew about fish diseases and pathogens. It is believed that this awareness will enable them to identify when there is risk on their farm and steps to be taken. Nearly $60.4 \%$ of the respondents had occasionally witness disease outbreak on their farm, about $61.1 \%$ believed that majority of disease outbreaks occurred at the juvenile stage which may be as a result of the source from which the juvenile were purchased, or they may be prone to stress from 
Table 1. Some socio-economic characteristics of the fish farmers $(n=144)$.

\begin{tabular}{|c|c|c|c|}
\hline Variables & Freq. & Percentage (\%) & Mean \\
\hline \multicolumn{4}{|l|}{ Marital Status } \\
\hline Single & 34 & 23.6 & \\
\hline Married & 110 & 76.4 & \\
\hline \multicolumn{4}{|l|}{ Household size } \\
\hline Less than 4 & 41 & 28.5 & \\
\hline $4-5$ & 62 & 43.1 & \\
\hline $6-8$ & 35 & 24.3 & 2.04 \\
\hline Above 8 & 6 & 4.2 & \\
\hline \multicolumn{4}{|l|}{ Age } \\
\hline Less than 30 & 19 & 13.2 & \\
\hline 30- 49 & 94 & 65.3 & 40.48 \\
\hline $50-59$ & 20 & 13.9 & \\
\hline 60 and above & 11 & 7.6 & \\
\hline \multicolumn{4}{|l|}{ Land ownership } \\
\hline Owned & 88 & 61.1 & \\
\hline Leased & 33 & 22.9 & \\
\hline Rented & 18 & 12.5 & \\
\hline Borrowed & 5 & 3.5 & \\
\hline \multicolumn{4}{|c|}{ Average monthly income from all sources } \\
\hline Less than $\mathrm{N} 30,000$ & 19 & 13.2 & \\
\hline N 30,000- N50,000 & 45 & 31.3 & \\
\hline N 51,000- N70,000 & 28 & 19.5 & \\
\hline Above N70,000 & 52 & 36.1 & \\
\hline
\end{tabular}

Source: Field Survey

1USD \$ = N440 (Parallel market exchange rate)

Table 2. Management practices of the respondents $(n=144)$.

\begin{tabular}{lcc}
\hline Variables & Freq. & Percentage (\%) \\
\hline Type of fish culture & 134 & 93.1 \\
Monoculture & 10 & 6.9 \\
Polyculture & & 90.3 \\
Culture Species & 130 & 2.8 \\
Clarias & 4 & 6.9 \\
Tilapia & 10 & 73.6 \\
Clarias/Tilapia & & 24.3 \\
Scale of operation & 106 & 2.1 \\
Small scale production (< 1ha) & 35 & 18.8 \\
Medium scale production (1-2.5ha) & 3 & 33.3 \\
Large scale production (>2.5ha) & & 26.4 \\
Volume of production per cycle & 27 & 21.5 \\
Less than 1 ton & 48 & \\
1 - 2 tons & 38 & \\
3 - tons & 31 & \\
Above 5 tons & & \\
\hline
\end{tabular}

Table 3. Level of awareness of fish farmers in Ekiti state on fish disease

\begin{tabular}{lcc}
\hline Variable & Frequency & Percentage (\%) \\
\hline Do you know about fish diseases and pathogens & & 91.00 \\
Yes & 131 & 09.00 \\
No & 13 & 13.90 \\
Frequency of disease outbreak & & 60.40 \\
Always & 20 & 25.70 \\
Occasionally & 87 & 9.7 \\
Never & 37 & 61.1 \\
Size of affected fish & & 9.0 \\
Fry & 14 & 7.6 \\
Juvenile & 88 & 2.1 \\
Grow out & 13 & 10.4 \\
Fingerling/Grow out & 11 & 3 \\
None & 15 & \\
\hline
\end{tabular}


rough handling during transportation to the farm while $78.5 \%$ of the respondents had experienced outbreak of fish disease on their farms as a result of poor management practices.

\section{Risk Factors Identified by the Fish Farmers}

Table 4 showed that $63.0 \%$ of the respondents indicated that flooding was the main source of pollution into their fish farm, causing the introduction and/ or spreading of pathogen and diseases on farm resulting in fish kill. Also, $36.1 \%$ of the respondents indicated that predators that gain entrance into their farm were also carriers of disease causing organisms thus their removal would reduce the spread of infectious diseases. Fortyfive point eight percent $(45.8 \%)$ of the respondents made use of stream/river water for culturing of fish, $14.6 \%$ used well water, $28.5 \%$ borehole, $9.0 \%$ claimed they used spring, while $2.1 \%$ used rain water, which they do not screen for pathogen before use.

\section{The Constrains Faced by Fish Farmers in Adopting Biosecurity Measures}

Constrains faced by the respondents in adopting biosecurity measures is as presented in Table 5 . They include high cost of facilities, lack of assistance, lack of proper biosecurity knowledge, expensive laboratory charges, inadequate monitoring by extension agents, lack of knowledge on prophylactic treatment, inaccessible laboratory, lack of fund, lack of awareness, lack of pathogen free water source, biosecurity measures are costly, disinfection/ foot dip poses effect on footwear, lack of disease free/certified fish seed source, spray of disinfectant is preferable to foot dip/ hand-wash, large household size can affect level of compliance to biosecurity measures, relatives/friends/staff access not easy to control, biosecurity measures are unreliable, lack of adequate land for separation of units/facilities and changing/ showering on the farm is not convenient.

\section{Discussion}

\section{Socio-economic Characteristics of the Respondents}

The result of the socio-economic characteristics of the fish farmers were in line with the works of Omitoyin and Sanda (2013), Thompson and Mafimisebi (2014), who revealed that majority of the respondents in their study were married thus the farmers would be expected to strive to embark on the management strategies that will avert diseases outbreak on their farm and enable them to be able to make profit for the use of their family wellbeing. The household size range is similar to the findings of Omitoyin and Fawehinmi, 2016 in Osun State but lower compared with the result of Akwanyi et al. (2019) who reported that fish farmers in Kakamega County, Kenya have an average of 7 members which indicated that they are likely to use family labour at their fish farms and this reduces production cost. However, Pandey, D.K. and Upadhayay (2012) in their work in Kulubari, West Tripura concluded that family size that is more than 5 is a larger family size. Also Silva et al. (2016) affirmed that larger households normally tend to have higher productivity as a result of availability of more labour, which most times are free, thus increasing the profitability of the venture. According to Ngeywo et al. (2015) age is a key factor in productivity and profitability performance of the farmer. It was observed that many of the fish farmers are still in their productive ages which is in agreement with the work of Apata (2012), Omitoyin and Fawehinmi, (2016). Younger people tend to be more energetic, adjust faster, and adopt new technologies, thus may be more productive than the elderly who may be more conservative. Pandey and Upadhayay (2012)

Table 4. Risk factors identified by the fish farmers.

\begin{tabular}{lcc}
\hline Variables & Freq. & Percentage (\%) \\
\hline Source of pollution & 24 & 16.7 \\
Agricultural waste & 4 & 2.8 \\
Industrial waste & 14 & 9.7 \\
Household waste & 73 & 50.7 \\
Flood & 29 & 20.1 \\
None & & 6.9 \\
Points of entry of pollutants & 10 & 36.1 \\
Vector & 52 & 7.6 \\
Predators & 11 & 9.7 \\
Wild fish & 14 & 11.1 \\
Pollutant & 16 & 4.2 \\
All & 6 & 24.3 \\
Vector/predator & 35 & 2.1 \\
None & & 45.8 \\
Source of water & 3 & 14.6 \\
Rain water & 36.5 \\
Stream River & 66 & 9.0 \\
Well water & 21 & 2 \\
Borehole & 41 & 13 \\
Spring & & \\
\hline
\end{tabular}


Table 5. Constrains faced by the respondents in adopting biosecurity measures.

\begin{tabular}{|c|c|c|c|}
\hline Variables & Mean & Std. Deviation & Rank \\
\hline High cost of facilities & 2.9097 & 1.13995 & 1 \\
\hline Lack of assistance & 2.8542 & 0.81908 & 2 \\
\hline Lack of proper biosecurity knowledge & 2.8194 & 1.126 & 3 \\
\hline Expensive laboratory charges & 2.8056 & 1.33421 & 4 \\
\hline Inadequate monitoring by extension agents & 2.7708 & 1.26667 & 5 \\
\hline Lack of knowledge on prophylactic treatment & 2.7153 & 1.04221 & 6 \\
\hline Inaccessible laboratory & 2.6458 & 1.15552 & 7 \\
\hline Lack of fund & 2.6111 & 1.36955 & 8 \\
\hline Lack of awareness & 2.5694 & 1.28277 & 9 \\
\hline Lack of pathogen free water source & 2.4931 & 0.92363 & 10 \\
\hline Biosecurity measures are costly & 2.4514 & 1.02983 & 11 \\
\hline Disinfection/ foot dip poses effect on footwear & 2.4306 & 1.23839 & 12 \\
\hline Lack of disease free/certified fish seed source & 2.375 & 1.46223 & 13 \\
\hline Spray of disinfectant is preferable to foot dip/ hand-wash & 2.3472 & 1.1363 & 14 \\
\hline Large household size can affect level of compliance to biosecurity measures & 2.3403 & 0.88628 & 15 \\
\hline Relatives/friends/staff access not easy to control & 2.2708 & 1.20731 & 16 \\
\hline Biosecurity measures are unreliable & 2.2708 & 1.32864 & 17 \\
\hline Lack of adequate land for separation of units/facilities & 2.25 & 1.06764 & 18 \\
\hline Changing/ showering on the farm is not convenient & 2.0347 & 1.39135 & 19 \\
\hline Wearing jumpsuit/overall on the farm is not convenient & 1.9653 & 1.24267 & 20 \\
\hline Wearing rain boot on the farm is not convenient & 1.9306 & 1.19821 & 21 \\
\hline Disinfection, hand-wash/ foot dip can affect make-up, cream, pedicure/manicure & 1.7847 & 1.31778 & 22 \\
\hline Disinfection, hand-wash/ foot dip can affect the skin & 1.7639 & 1.18844 & 23 \\
\hline Biosecurity measures are time consuming & 1.6806 & 1.37232 & 24 \\
\hline
\end{tabular}

reported that more participation of young and middle age group of peoples in fish production in the Tripuna. The work of Kumar et al. (2015) showed a shifting pattern from old age to young age which means that aquaculture is drawing the attention of the younger age bracket. Personal ownership of the land on which farming activities was carried out is in tandem with the works of Hasan et al., (2013) and Olasunkanmi, (2012). Availability of owned land by the fish farmers would make it possible for them to be able to have adequate land space for expansion facilities, maximum biosecurity measures and for fish production expansion. Ugwuba and Chukwuji 2010 in their study however reported lack of land for pond establishment as one of the constraint to aquaculture in eastern part of Nigeria. Susilowati et al. (2011), is also of the opinion that farm ownership type may have influence on biosecurity adoption. Extra source of income is needed to enable fish farmers adopt necessary biosecurity measures that will enhance fish production through diseases reduction. According to Diiro (2013) off- farm income is expected to provide farmers with some capital for purchasing productive inputs such as improved fish seed, feed, lime and fertilizers. Reardon et al., (2007) considered off-farm income as an important strategy for rural households to overcome credit constraints in many developing countries.

\section{Fish Farming Management Systems in the Study Area}

The involvement of most the respondents in monoculture, is similar to the work of Omobepade, et al., 2014, Okpeke et al., 2015 and Olatunji and Ogunyemi (2016) who observed same trend. Kudi, et al.,
(2008) attested to higher profitability of catfish production over other types of fish. Catfish is poly cultured with Tilapia for two major reasons, to reduce precocious reproductive nature of the Tilapia (Fagbenro, 2004) and to provide extra income for the farmers. Limbu et al., 2016 and Shoko et al., 2016 observed similar trend in their work among small scale farmers in Tanzania. The small scale nature of the fish farmers with a land size less than 1 hectare is a big challenge to mechanisation. Land could be affected by lack of access to credit facility and this might impede expansion of farm and its availability for building of separate facilities for effective biosecurity measures and also reduce farmers' income. The result is in agreement with the work of Adebo and Ayelari (2011) who found that majority of the fish farmers in Ekiti and Ondo States had less than 1 ha of fish farm. However, it is not in line with Okere and Adeleye, 2014 who reported that the fish farmers in their study areas claim to be operating large scale fish production systems. The low fish production might not be unconnected with the small scale production level. There is thus the need for the farmers to be assisted in order to expand the scope of their business to meet the protein requirement and demand of the people. A number of studies have indicated that agricultural production in Nigeria is still characterised by small farm holders (Ijere and Mbanasor, 2000). According to Abah and Petja (2015) factors such as inadequate access to adequate land, traditional methods of cultivation, inadequate access to credit, inadequate processing and storage facilities, small farm size, and inadequate access to farm inputs will lead to lower production. 


\section{Level of Awareness of Fish Farmers in Ekiti State on Fish Disease}

The fish farmers' awareness of fish diseases will enable them to identify when there is risk on their farm and steps to take to minimise it. Subedi et al. (2009) in Yunnan Province, China and Okunlola (2010) in Delta State, Nigeria are of the opinion that consciousness and awareness will leads to better adoption which will enable decision makers make informed decisions on their farms for sustainability. Occasionally disease outbreak as witnessed on the farm as a result of poor management practices is in line with the work of Okeke and Adeyemo (2014), Maina et al. (2017), while disease outbreaks occurring at the juvenile stage may be as a result of the source from which the juvenile was purchased, or be prone to stress from rough handling during transportation to the farm. Obosi and Agbeja, 2015 reported that majority of the farmers in their study area bought fish seeds from another farm where the source was not ascertained or certified. This practice is against the FAO recommendation that the purchase of fingerlings/post larvae should be from producers selling certified Specific Pathogen Free (SPF) stock. This will curtail the introduction and spread of infectious disease leading to fish mortality.

\section{Risk Factors Identified by the Fish Farmers}

Flood was observed to be the main source of pollution into their fish farm, causing the introduction and/ or spreading of pathogen and diseases on farm resulting in fish kill. Adebo and Ayelari (2011) reported in their work that majority of fish farmers in Ekiti state experienced flooding resulting in great loss with more than half of them loosing between 3501 to 5000 fishes at a time and thereby concluded that most of them did not embark on any control measures. Predators that gain entrance into the farm were also carriers of disease causing organisms. According to Okwodu (2016), predators in fish pond include birds, frogs, snakes, insects, and carnivorous fish. Their removal will reduce the spread of infectious diseases. Stream/river, well water, borehole, spring, rain water, must be screened for pathogen before use. This is in agreement with the works of Maina et al. (2017) and Mavuti et al. (2017) in Kenya who reported that rivers are the main pond water sources. However, Mdegela et al. (2011) in Tanzania, reported highest infestation rate with intestinal parasites in fish farms where river water is mostly used.

\section{The Constrains Faced by Fish Farmers in Adopting Biosecurity Measures}

The perception of the fish farmers on the constraints they faced in adopting biosecurity measures is akin to the discovery of Awotide et al. (2016), that farmers in rural Nigeria with access to credit or farm support are more likely to participate in adopting new technologies including biosecurity measures. In the opinion of Ayoade and Akintonde (2012) in Osun State, Nigeria unbalanced visits and unsatisfactory trainings from the extension representatives have resulted in reluctance or late acceptance of innovations by farmers. Gangasagare and Karanjkar (2009) in Maraathwada Region of Maharashtra also noted that majority of farmers did not care to vaccinate and accept other health measures for their animals. Ashraf et al. (2013) in Punjab, Pakistan opined that farmers do not have technological knowledge and they lack resources to create interest toward technical attainments. More importantly, role of extension field staff was negligible. Brennan and Robert (2012) drew a conclusion from their study in North-West England that even though some farmers were observing a set of biosecurity measures, these they do once in a blue moon or in an inappropriate manner because of their perception such as: lack of established effectiveness of practices, insufficient fund, unavailability of time, lack of appropriate training of veterinary surgeons, manufacturers and other herd animal specialists. Yanong and Erlacher-Reid (2012) is of the opinion that knowledge on biosecurity and fish health management assists in development of precautionary measures against disease outbreak.

\section{Conclusion}

In view of the great importance attached to adoption of biosecurity in reducing fish loss and improving fish production, this study presented information on the farmers' perceptions and the constraints they face in their effort towards adopting biosecurity practices. In conclusion, the farmers should be encouraged to obtain their fish seed from a reliable and diseased free source, carry out basic biosecurity measures, acclimatise their fish properly before stocking and these fish should be handled/transported with adequate care to minimise stress/damages that could increase their vulnerability to fish diseases. Farmers should be enlightened more on the importance and benefit of adequate biosecurity measures, be provided with accessible/affordable veterinary services and financial support, while the extension services should be strengthened to give adequate training to farmers on health management practices that will help in boosting their production, thereby enhancing food availability.

\section{Ethical Statement}

The work was basically a survey work using structured questionnaire and focus group discussion. No animal or live specimen trial was involved. Individual respondents/participants were duly briefed about the purpose and content of the project and only willing participants took part in the survey. An informed consent form was given to all participants to fill and append their signature and phone number. They were not under obligation or compulsion as no incentive or 
monetary gratification was given. Dissemination of the research findings to improve their productivity and performance is ongoing. This should have been completed if not for the lockdown as a result of the COVID-19 pandemic.

\section{Funding Information}

The authors received no specific funding for this work.

\section{Author Contribution}

S.O.; Conceptualization, Methodology, Formal Analysis, Resources, Writing (Reviewing \& Editing), Supervision, and Project Administration. K.O.; Formal Analysis, Investigation, Resources, and Visualization.

\section{Conflict of Interest}

The authors declare that they have no known competing financial or non-financial, professional, or personal conflicts that could have appeared to influence the work reported in this paper.

\section{Acknowledgements}

We (Siyanbola A. Omitoyin and Kemisola D. Osakuade) acknowledge the extension agents who assisted in the data collection (distribution and retrieval of the questionnaire) in Ekiti State.

\section{References}

Abah, R. C., \& Petja, B. M. (2015). The Socio-economic Factors affecting Agricultural Development in the Lower River Benue Basin. Journal of Biology, Agriculture and Healthcare, 5(24):84-94

Adams, F., \& Ohene-Yankyera, K. (2015). Determinants of Small Ruminant Farmers' Decision to Participate in Veterinary Services in Northern Ghana. Journal of Veterinary Medicine and Animal Health, 7(5): 193-204

Adebo, G. M., \& Ayelari, T. A. (2011). Climate Change and Vulnerability of Fish Farmers in Southwestern Nigeria. African Journal of Agricultural Research 6 (18): 4230 4238.

Aftabuddin, S., Islam, M.N., Bhuyain, M.A.B. Mannan, M.A. and Alam, M.M. (2016): Fish Diseases and Strategies taken by the Farmers in Freshwater Aquaculture at Southwestern Bangladesh. Bangladesh Journal of Zoology. 44(1): 111122.

Agbo, D. A. (2015). Bridging the Fish Demand and Supply Gap in Nigeria. Retrieved from, http://www.dailytrust.com.ng/daily/index.php/agricult ure/54661-bridging-thefish- demand-supply-gap-inNigeria on 12/03/2019.

Akwanyi, O. W., Wakhungu, W. J. and Obiri, F. J. (2019): Demographic and Socioeconomic Characteristics of Fish Farmers and their Effects on Fish Farming Management Practices in Kakamega County, Kenya. International Journal of Scientific and Research Publications, $9(11): 358-368$.
Apata, O. M. (2012). Awareness and Adoption of Fish Production Technologies in South-Western, Nigeria. Journal of Emerging Trends in Engineering and Applied Sciences, 3(5):819-822

Aquaculture in Nigeria Fact Sheet 2019. Accessed from: file://C:/Users/Dell\%20Mini/Downloads/Aquaculture+i n+Nigeria\%20(1).pdf on 5/8/2020

Ashraf, S. M., Iftikhar, G.A. Khan, B., Shahbaz., \& Ashraf, I. (2013). Performance Evaluation of Diary Farmers Regarding Adopting of Precise Diary Farming Practices in the Punjab, Pakistan. African Journal of Agricultural Research, 8(29): 4074-4080.

Assefa, A., \& Abunna, F. (2018). Maintenance of Fish Health in Aquaculture: Review of Epidemiological approaches for Prevention and Control of Infectious Disease of Fish. Veterinary Medicine International.10.

Awotide, B. A., Karimov, A. A., \& Diagne, A. (2016). Agricultural Technology Adoption, Commercialization and Smallholder Rice Farmers' Welfare in Rural Nigeria. Agricultural Economics, 4(3).

Ayoade, A. R., \& Akintonde, J. O. (2012). Constraints to Adoption of Agricultural Innovations among Women Farmers in Isokan Local Government Area, Osun State. International Journal of Humanities and Social Science, 2(8):57

Bakare, H. A, Kareem, R. O, Babatunde, D, Akintaro, J. A., \& Arije, A. R. (2014): Democratic Governance and Poverty Alleviation: Empirical Study of Ekiti State, Nigeria. Global Journal of Commerce \& Management Perspective. 3(6): 94-101

Brennan, M. L., \& Robert, C. M. (2012). Biosecurity on Cattle Farms: A Study in North-West England. PloS One, 7 (1), e28139. Accessed from https://journals. plos.org/plosone/article?id=10.1371/jo urnal.pone.0028139 on 20/08/2020.

Brun, E., Rodgers, C. Georgiadis, M., \& Bjorndal, T. (2009). Economic Impact of Disease and Biosecurity Measures. International Biosecurity Conference, Tronddheim, Norway. August 17-18, 2009

Diiro G. M. (2013). Impact of Off-farm Income on Agricultural Technology Adoption Intensity and Productivity Evidence from Rural Maize Farmers in Uganda. International Food Policy Research Institute, Working Paper 11.

Fagbenro, O. A. (2004). Predator Control of Overpopulation in Cultured Tilapias and the Alternative Uses for Stunted Tilapias in Nigeria. Proceedings of the Sixth International Symposium on Tilapia in Aquaculture, 634-647. (R.B. Bolivar, G.C. Mairand K. Fitzsimmons, eds.). Manila, Philippines.

Food and Agriculture Organization (FAO) (2012). The State of World Fisheries and Aquaculture, FAO Fisheries and Aquaculture Department Publications, Rome, Italy.

FAO (2014). Sustainable Fisheries and Aquaculture for Food Security and Nutrition. Food and Agriculture Organization of the United Nations. Retrieved from http://www.fao.org/documents/card/en/c/63d4de9f50df-49b1-b6d2-b7d0368744ea.

Gangasagare, P. T., \& Karanjkar, L. M. (2009). Constraints in Adapting Animal Husbandry Practices by the Diary Farmers in the Maraathwada Region of Maharashtra. Veterinary World, 2(9):347-349.

Hasan, M. M., Faruk, M. A. R., Anka, I. Z., \& Azad M. A. K. (2013). Investigation on Fish Health and Diseases in Rural Pond Aquaculture in three Districts of Bangladesh. 
Journal of the Bangladesh Agricultural University 11(2): 377-384.

Huicab-Pech, Z. G., Landeros-Sánchez, C., \& CastañedaChávez, M. R. (2016). Current State of Bacteria Pathogenicity and their Relationship with Host and Environment in Tilapia (Oreochromis niloticus). Journal of Aquaculture Research and Development. 7(5):428

Ijere, M. O., \& Mbanabor, J. (2000). Agribusiness Development and Nigeria Agriculture. In Nwosu, A. C et al (ed) Agricultural Transformation in Nigeria. Owerri. Novelty Industrial Enterprises Limited.

Karataş E. and Karataş A. (2017): The importance of fishery production as an income source in Turkey. Journal of Survey in Fisheries Sciences; 4(1):38-53.

Koblentz, G. D. (2010). "Biosecurity Reconsidered: Calibrating Biological Threats and Responses". https://doi.org/10.1162/isec.2010.34.4.96

Kudi, T. M., Bako, F. P., \& Atala T. K. (2008). Economics of Fish Production in Kaduna State Nigeria. Journal of Agricultural and Biological Sciences, 3(5 \& 6):121-124.

Kumar, P., Khar, S. Sharma, R., Choudhary, P., Himabindu, K.V., Sharma, S. Sharma, S.K. and Jagmohan, S. (2015): Identifying Socio-Economic Features of Fish Farmers. An International Journal of Agro Economist. 2(1):29 34

Limbu, S. M., Shoko, A. P., Lamtane, H. A., Shirima, E. D., KisheMachumu, M. A., Mgana, H. F., \& Mgaya, Y. D. (2015). Effect of Initial Stocking Size of the Predatory African Sharptooth Catfish (Clarias gariepinus) on Recruits, Growth Performance, Survival and Yield of Mixed-Sex Nile Tilapia (Oreochromis niloticus) in Concrete Tank Culture System. Internationa. Aquatic Research. 7: 6373.

Limbu, S. M., Shoko, A. P., Lamtane, H. A., Kishe-Machumu, M. A., Joram, M. C., Mbonde, A. S., Mgana, H. F., \& Mgaya, Y. D. (2016). Fish Polyculture System Integrated with Vegetable Farming Improves Yield and Economic Benefits of Small-Scale Farmers. Aquaculture Research, 48(7) .

Maina, K.W., Mbuthia, P.G., Waruiru, R.M. Nzalawahe, J. Murugami, J.W. Njagi, L.W. Mdegela, R.H. and Mavuti, S.K. (2017): Risk factors associated with parasites of farmed fish in Kiambu County, Kenya. International Journal of Fisheries and Aquatic Studies; 5(4): 217-223

Mavuti, S.K, Waruiru, R.M, Mbuthia, P.G., Maina, J.G., Mbaria, J.M., Otieno, R.O. (2017): Prevalence of ecto- and endoparasitic infections of farmed Tilapia and Catfish in Nyeri County, Kenya. Livestock Research for Rural Development. Volume 29, Article \#122. Retrieved July 4, 2017, http://www.Irrd.org/Irrd29/6/stek29122.htm

Mdegela, R.H., Omary, A., Mathew, N.C., Nonga, H.E. (2017): Effect of pond Management on Prevalence of Intestinal Parasites In Nile Tilapia (Oreochromis niloticus) Under Small Scale Fish Farming Systems in Morogoro, Tanzania. Livestock Research for Rural Development Volume 23, Article \#127. Retrieved July 11, 2017, from http://www.Irrd.org/Irrd23/6/mdeg23127.htm

Mutibvu, T., Maburutse, B. E., Mbiriri, D. T., \& Kashangura, M. T. (2012). Constraints and Opportunities for Increased Livestock Production in Communal Areas: A Case Study of Simbe, Zimbabwe. Livestock Research for Rural Development, 24. Article \#165. Retrieved February 3, 2018, from http://www.Irrd.org/Irrd24/9/muti24165.htm.

Ngeywo J., Basweti E., \& Shitandi, A. (2015). Influence of
Gender, Age, Marital Status and Farm Size on Coffee Production: A Case of Kisii County, Kenya. Asian Journal of Agricultural Extension, Economics \& Sociology, 5 (3), 117-125.

Nmadu, J. N., Sallawu, H., \& Omojeso, B. V. (2016). SocioEconomic Factors Affecting Adoption of Innovations by Cocoa Farmers in Ondo State, Nigeria. European Journal of Business, Economics and Accountancy, 3(2): 20566018

Noga E. J. (2010). Fish Disease: Diagnosis and Treatment. 2nd. Hoboken, NJ, USA: Wiley Blackwell; 2010.

Obosi, K., \& Agbeja, Y. E. (2015). Assessing the Level of Aquaculture Biosecurity Regulations Compliance in Ibadan, Nigeria. Donnish Journal of Agricultural Research, 2(3):012-019.

Odoh, V. U., Abuh, O. O., Haruna, M. M., Yisa, M. A., \& Bids, A. A. (2019). Medically Important Parasites of Clarias garipienus (Catfish) in Nigeria. Advances in Biotechnology and Microbiology. 15(1): 555904.

Okpeke, M. Y., \& Akarue, B. O. (2015). Analysis of the Profitability of Fish Farming in Warri South Local Government Area of Delta State, Nigeria. IOSR Journal of Agriculture and Veterinary Science, 8(12): 45-51

Okunlola, J Olaniyi (2010) Factors influencing adoption of rubber-based techniques among small-holder farmers in Delta State, Nigeria.

Journal of Food, Agriculture \& Environment 8 (2):391394

Okwodu, N. E. (2016). Aquaculture for Sustainable Development in Nigeria. World Scientific News, 47(2) 151-163

Olasunkanmi, J. B. (2012). Economic Analysis of Fish Farming in Osun State. South-Western Nigeria. In: Proceedings of the 16th Biennial Conference of International Institute for Fisheries Economics and Trade, Tanzania. https://core.ac.uk/download/pdf/10196126.pdf

Olatunji S. O., \& Ogunremi J. B. (2016). Assessment of Awareness and Adoption of Fish Farming Technologies in Obio-Akpor Local Government Area of Rivers State, Nigeria. The Journal of Agricultural Sciences, 11(3):147154.

Olujobi, O. J., Sale, F. A., \& Akande, O. M. (2013). Effect of Wildlife Species on the activities of Agroforest Farmers in Ekiti State. Journal of Agriculture and Environmental Sciences, 1(1):24-35

Omobepade B. P., Adebayo O. T., \& Amos T. T. (2014). Technical Efficiency of Aquaculturists in Ekiti State, Nigeria. Journal of Aquaculture Research and Development 5(5):252

Onyekuru, N. A., Ihemezie, E. J., \& Chima, C. C. (2019). Socioeconomic and Profitability Analysis of Catfish Production: a case study of Nsukka Local Government Area of Enugu State, Nigeria. Agro-Science, 18 (2): 51-58.

Pandey, D.K. and Upadhayay, A. D. (2012): Socio-Economic Profile of Fish Farmers of an Adopted Model quaculture Village: Kulubari, West Tripura. Indian Research Journal of Extension Education, Special Issue, 2: 65-68.

Reardon, T., Stamoulis, K., \& Pingali, P. (2007). “Rural Nonfarm Employment in Developing Countries in an Era of Globalization." Agricultural Economics, 37:173-183.

Shava, E., \& Gunhidzirai, C. (2017). 'Fish Farming as an Innovative Strategy for Promoting Food Security in Drought Risk Regions of Zimbabwe', Jàmbá: Journal of Disaster Risk Studies 9(1): 491. 
Siddiqa, A., Shahroz, M.H., Barman, B.K., Ahmed, M.U., and Chakraborty, B.K. (2018): Production Economics and Profitability Analysis of Aquaculture in Southwest Bangladesh. International Journal of Oceanography \& Aquaculture 2(6): 000156.

Silva, N., \& Broekel, T. (2016). Factors Constraining Farmers' Adoption of New Agricultural Technology Programme in Hambantota District in Sri Lanka: Perceptions of Agriculture Extension Officers. University of Sri Jayewardenepura, Sri Lanka, 13th International Conference on Business Management (ICBM) 2016, Available at SSRN: https://ssrn.com/abstract=2910350 or http://dx. doi.org/10.2139/ssrn.2910350)

Shoko, A. P., Limbu, S. M., Mrosso, H. D. J., Mkenda, A. F., \& Mgaya, Y. D. (2016). Effect of Stocking Density on Growth, Production and Economic Benefits of Mixed Sex Nile Tilapia (Oreochromis niloticus) and African sharp tooth. Aquaculture Research, 47(1):36-50

Smith, S. A. (2012). Biosecurity and Fish Health Monitoring for Aquaculture Facilities. Proceedings $2^{\text {nd }}$ International Conference on Recirculating Aquaculture 22-24

https://freshwater-aquaculture.extension.org/wpcontent/uploads/2019/08/Proceedings_2 ${ }^{\text {nd }}$ _International_Conference_on_Recirculating_Aq.pdf\#p age $=31$

Subedi, M., Hocking, T. J., Fullen, M. A., McCrea, A. R., Milne, E., Bozhi, W. B., \& Mitchell, D. J. (2009): An AwarenessAdoption Matrix for Strategic Decision Making in Agricultural Development Projects: A Case Study in
Yunnan Province, China. Agricultural Sciences in China, 8(9): 1112-1119

Susilowati, S.H., Iqbal, M., Patrick, I. and Jubb, T. (2011): Factors influencing the adoption of biosecurity activities on broiler and layer farms in Indonesia. Australian Agricultural and Resource Economics Society National Conference Melbourne, Feb 8th to 11th, 2011

Thompson, O. A., \& Mafimisebi, T. E. (2014). Profitability of Selected Ventures in Catfish Aquaculture in Ondo State, Nigeria. Fisheries and Aquaculture Journal, 5(2):096.

Ugwuba, C. O. A., \& Chukwuji, C. O. (2010). The Economics of Catfish Production in Anambra State, Nigeria: A Profit Function Approach. Journal of Agriculture and Social Sciences, 6(4): 105-109.

UNCTAD (2018). Achieving the Targets of Sustainable Development Goal 14: Sustainable Fish and Seafood Value Chains and Trade. 36 pages. UNCTAD/DITC/TED/MISC/2018/2

United Nation (2017). Department of Economic and Social Affairs. Accessed from: https://www.un.org/development/desa/en/news/popu lation/world-population-prospects-2017.htmlon $5 / 8 / 2020$

Yanong, P. E. R., \& Erlacher-Reid, C. (2012). Biosecurity in Aquaculture, Part 1: An Overview. Southern Regional Aquaculture Center Publication, No. 4707

Ye, Y., and Cochrane, K., 2011. Global overview of marine fishery resources. http://www. fao. Org/ docrep/015/i2389e/i2389e.pdf 